$$
\text { 구강의 외과적 해부학 }
$$

한림대학교 의과대학 이비인후-두경부외과학교실

주 형 로

\title{
Surgical Anatomy of the Oral Cavity
}

\author{
Hyung Ro Chu, MD \\ Department of Otorhinolaryngology-Head and Neck Surgery, College of Medicine, Hallym University, \\ Chuncheon, Korea
}

\section{서 론}

구강 악성종양은 전체 두경부암의 $30 \%$ 를 차지하며, 95\% 이상이 표피양암종(epidermoid carcinoma) 이다. 2001년 우리나라 통계에서 보면 구강암은 $16.5 \%$ 이며, 그 중 설암이 $49.7 \%$ 로 가장 많았고 다음으로는 구강 저암, 협점막의 순이었다.

구강에서 발생한 종양에 대한 치료 목표는 일차적으 로 종양을 완전히 제거하는데 있으며, 이차적으로는 형 태와 기능을 유지하는데 있다. 구강암의 치료에 있어서 20세기 초에는 암의 완전 제거가 주된 목표였으나, 60년 대에 들어서면서 하악을 보존하는 경향이 뚜렷해 졌으며, 최근 30년간 근피판이나 유리피판 등을 이용한 재건술 의 비약적인 발전으로 술 후 발성과 연하 기능의 빠른 회복을 기대할 수 있게 되었다.

구강암의 외과적 절제는 두개저(skull base)나 경추 (cervical spine), 또는 피부에 광범위한 침습이 있는 경 우를 제외하고는 한계가 없다. 구강은 해부학적으로 중 요한 구조물들이 특별한 방어막이 없이 연속되어 있으 므로 종양학적으로 적합한 절제를 위해서는 이러한 구 조물들이 희생될 수 있다. 본란에서는 구강암 치료에서

교신저자 : 주형로, 200- 704 강원도 춘천시 교동 153번지 한림대학교 의과대학 이비인후- 두경부외과학교실 전화 : (033) 252- 9970. 전송 : (033) 241- 2909 E- mail : hrchu@ hanmail.net
종양학적으로 만족스런 절제를 시행함과 동시에 기능유 지에 중요한 구조물들을 보존할 수 있는 기초적인 해부 학적 관계를 알아보고자 한다.

구강은 구순(lip)의 순홍부(vermilion)와 피부의 경 계에서 시작하여, 상부는 경구개(hard palate) 와 연구개 (soft palate)의 경계면, 하부는 유곽유두(circumvallate papillae), 양쪽 측면은 구개설근(palatoglossus muscle) 으로 이루어진 편도의 전주(anterior tonsillar pillar)까 지를 이른다. 구강을 이루는 7 가지 해부학적 구조로는 구순, 협부점막(buccal mucosa), 상하치조능(alveolar ridge), 구후삼각(retromolar trigone), 경구개, 구강저 (floor of mouth), 그리고 구강설(oral tongue, mobile tongue) 이 있다(Fig. 1).

\section{구 순(Lips)}

구순의 해부학적 경계는 A merican Joint Committee on Cancer(AJCC)의 정의에 따르면," 피부와 순홍부 (vermilion) 의 경계에서 시작하여 단지 순홍부 면만을 포함하거나, 또는 상하구순의 접촉면만을 포함한다. 즉, 구각(commissures of mouth)에 연결되는 상하구순에 한정된다." 라고 되어있다. 이 정의는 구순과 인접한 피 부에서 발생한 피부 악성종양이나 구순의 내측 점막에 발생한 협부점막 암종이 구순암에 포함되지 않도록 주 의를 기울여야 함을 강조하고 있다.

구순암은 88 98\% 가 하구순에 발생하며, 상구순은 


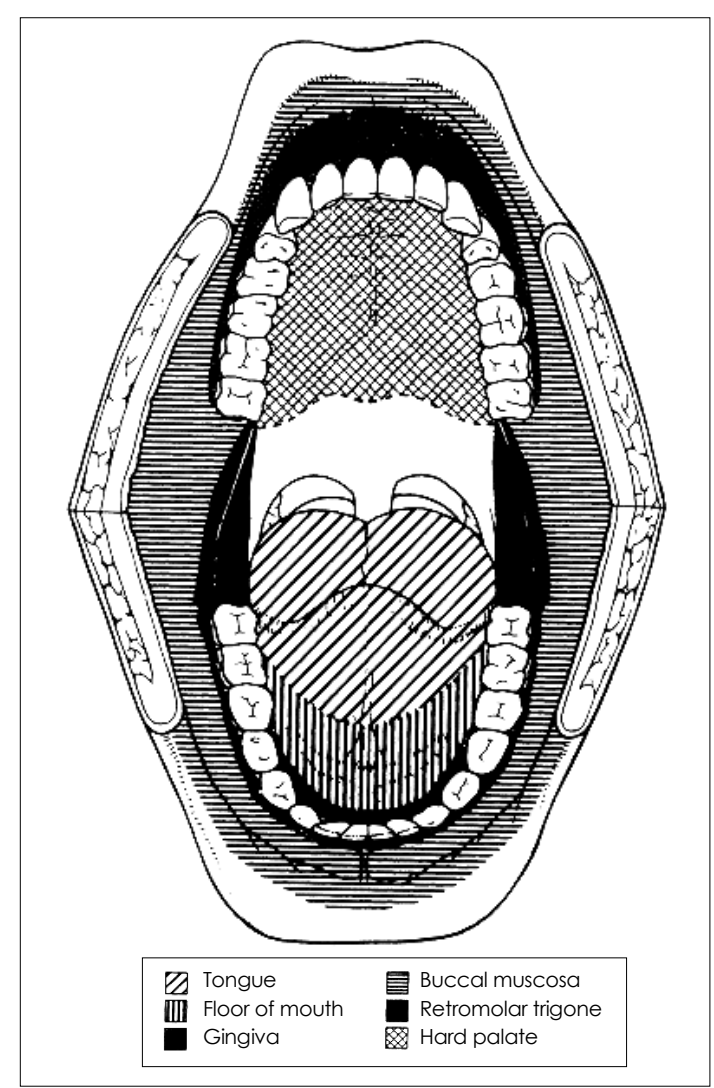

Fig. 1. Anatomic sites within the oral cavity.

2 7\% 의 빈도를 보이며 구각은 $1 \%$ 를 넘지 않는다. 구 순은 피부와는 달리 비각화중층편평상피(nonkeratinized stratified squamous epithelium)로 이루어져 있으며 점막하 선조직(glandular elements) 이 없어 쉽게 건조 해진다. 상피 이외의 구성 요소로는 혈관, 신경, 지방, 결 합조직(connective tissue) 과 근육으로 이루어져 있다. 구륜근(orbicularis oris muscle) 은 구순의 주된 근육으 로 구강의 괄약근으로 작용한다.

구순의 지각은 상구순이 5번 뇌신경(trigeminal nerve) 의 분지인 상악신경(V2)의 하안와신경( infraorbital nerve), 구각은 하악신경(V3)의 협신경(buccal nerve)의 지배 를 받으며, 하구순은 하악신경의 이신경(mental nerve) 의 지배를 받는다.

이신경이 통과하는 이공(mental foramen)은 하악골 암전이의 중요한 해부학적 통로가 된다. 이공은 주로 상

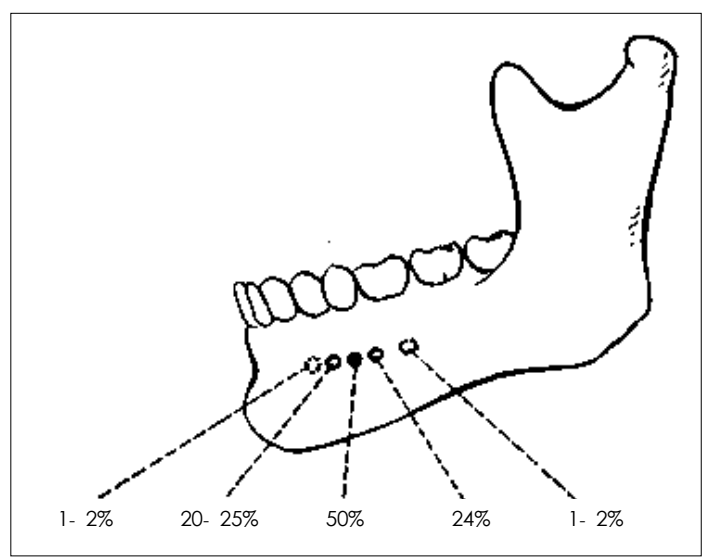

Fig. 2. Variations in the relation of the mental foramen to the roots of the teeth.

안와절흔( supraorbital notch) 에서 수직 연결선상에 위 치하며, 치아와의 관계에서는 $50 \%$ 에서 제 2 소구치의 치 근부에 위치한다Fig. 2). 연구보고에 따르면 구순암 환 자의 $22 \%$ 에서 림프집합관이 이공을 통과한다고 보고되 고 있다.

하구순의 림프액은 중간 $1 \beta$ 에서는 이악하림프절( submental lymph node) 로 유입되며, 외측 $1 / 3$ 은 각각 동 측 악하림프절( submandibular ly mph node) 로 유입된 다. 하구순의 중간부는 림프관의 교차유입이 일어나면 서 양측 악하절로 유입될 수 있으나, 외측 하구순의 경우 에는 동측으로만 유입된다. 상구순은 대부분 동측의 림 프절로 유입되는데, 일부는 전이개림프절(preauricular ly mpn node) 또는 이하선하림프절( infraparotid node) 로 유입되며, 하구순과 달리 교차유입은 일어나지 않는다.

구순암의 수술에서 가장 중요한 것은 정상 절제연을 확보하면서 완전하게 종양을 절제하는데 있으며, 그 다 음으로는 미용과 기능을 보존하는 것이 중요하다. 절제 방법이나 치료방침의 결정은 주위조직으로의 침윤의 정 도, 조직학적 형태, 림프전이절의 유무 등과 같은 종양 의 특성과 임상적 평가에 따라 이루어지게 된다.

\section{협부점막(Buccal Mucosa)}

협부점막은 구순의 내측 점막에서 상하치은협구(gingivobuccal sulcus) 까지를 이른다. 구강전정의 외측벽을 
구성하며 후방으로는 후구치치은(retromolar gingiva) 과 접한다.

협근(buccinator muscle) 은 인두의 상괄약근( superior constrictor)으로부터 시작하여 구륜근과 합쳐지면 서 oral competence를 형성한다(Fig. 3). 협부점막의 암종은 외측으로 진행하면 협근을 통하여 후방의 협부 지방조직 또는 협부의 점막하조직이나 피부를 침범할 수 있다. 협근은 안면신경의 협신경 분지가 운동신경을 지배하며, 동일한 주행경로를 가지는 하악신경(V3)의 협신경 분지가 지각을 담당한다. 이 외에 상악신경( V2) 의 하안와신경과 이신경(mental nerve)이 협부 전방부 의 감각을 담당한다.

림프계는 점막하 모세혈관망(submucosal capillary network)에서 시작하여 이악하림프절과 악하림프절로 유입된다.

협부점막 종양의 수술에서는 이하선관(Stensen' s duct) 에 주의하여야 한다. 이하선관이 일부 제한적으로 절제된 경우에는 전위(transposition) 와 재이식(reimplantation)이 필요하며, 완전히 절제되거나 희생된 경우 에는 결찰할 수도 있다.

\section{치조능(Alveolar Ridge)}

치조능은 상악골과 하악골의 치아를 지지하는 치조돌 기(alveolar process) 와 그 점막을 포함하며, 외측으로 는 치은협구( gingivobuccal sulcus) 에서 내측으로는 구

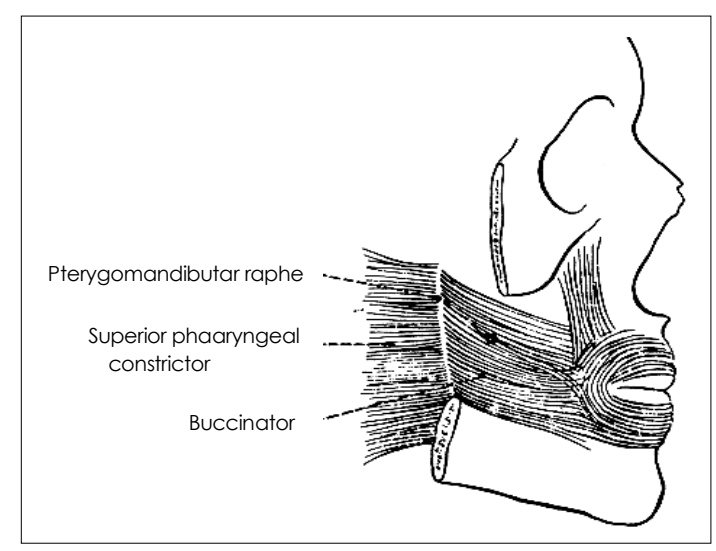

Fig. 3. The buccinator muscle. Note its continuity with fibers of the orbicularis oris and its posteriorly, at pterygomandibular raphe, with the superior constrictor. 강저(floor of mouth) 와 경구개에 이른다. 후방부는 하 치조능은 구후삼각(retromolar trigone), 상치조능은 상 악결절(maxillary tubercle)이 경계가 된다.

상악신경(V2)은 여러 분지를 통하여 상악의 치아와 치조능의 지각신경을 담당하며, 하악신경 (V3)은 하악의 치아와 치조능의 지각신경을 지배한다. 상악치아는 후상 치조신경( posterosuperior alveolar nerve) 과 전상치조 신경(anterosuperior alveolar nerve)이 담당하며, 상 치조능의 설측 점막은 전상악골(premaxilla) 부위는 비 구개신경(nasopalatine nerve), 전상악골 후방은 대구 개신경(greater palatine nerve) 이 담당하며, 구순측 점 막은 각각 하안와신경과 후상치조신경이 담당한다. 하악 치아는 하악관(mandibular canal) 을 지나는 하치조신경 (inferior alveolar nerve)이 감각신경을 이루며, 하치조 능의 설측 점막은 설신경(lingual nerve) 이 담당하고 구 순측 점막은 견치(canine tooth) 앞쪽은 이신경이, 뒤쪽 은 협신경이 담당한다.

상치조능의 구순측 림프액은 이악하림프절과 악하림프 절로 유입되고, 설측은 상심부경정맥림프절( upper deep jugular lymph node)과 외측후인두림프절(lateral retropharyngeal lymph node)로 주로 유입되며 일부는 이하선하림프절로 유입된다.

\section{구후삼각(Retromolar Trigone)}

구후삼각은 하악 제 3 대구치의 후면에서 상부로는 상 악결절에 이르는 하악의 상행지(ascending ramus) 를 덮고 있는 점막을 이른다.

점막은 골에 밀착되어 있어 악성종양이 발생하면, 하 악골에 침습되기 쉬우며, 하치조신경이 들어가는 하악관 (mandibular foramen)이 구후삼각 내측면의 중앙부 바 로 후방에 위치하여 조기침윤의 경로가 될 수 있다. 특히 이 부위의 종양에서 적절한 절제를 제한하는 요소는 익 구개와(pterygopalatine fossa) 와 구개저(skull base) 까지 침습한 경우이다.

신경지배는 제 9 뇌신경인 설인신경(glossopharyngeal nerve) 과 소구개신경( lesser palatine nerve, V2) 가 감각신경을 담당한다. 설인신경은 이 부위에 발생한 암종에서 연관이통(referred ear pain) 을 유발한다. 
림프액은 편도와 tonsillar fossa) 부위와 유사하여 상 심부경정맥림프절로 유입되며, 간혹 이하선하림프절과 외측후인두림프절로 유입된다.

\section{경구개(Hard Palate)}

경구개는 전방과 측방은 상치조능으로, 후방으로는 연 구개와의 경계면으로 구성되는 반월상의 영역이다.

양측 구개골의 수평판이 중앙에서 합쳐져 이차구개 (secondary palate) 를 구성하며, 양측 상악골의 구개돌 기가 합쳐지면서 일차구개(primary palate) 를 이룬다. 일차구개는 전상악골의 부분으로 절치(incisor teeth) 를 지지하는 골구조이다. 경구개 후방과 일차구개의 융합부 위는 절치와 (incisive fossa)에 의해 두드러진다. 절치 와에는 네 개의 구멍이 있으며 양측 비강으로부터 동맥 과 신경이 각각 통과하게 된다. 경구개의 골에는 두개의 골 봉합선( suture line) 이 있는데, 양측을 가르는 세로봉 합선( longitudinal suture line) 과 상악골과 구개골 사이 를 지나는 가로봉합선(transverse suture line) 이 그것 이다. 가로봉합선은 제 1 대구치와 제 2 대구치 사이에 위 치하며 치조돌기에 이르면서 돌기의 내측면을 따라 후 방으로 진행하면서 제 2 대구치 위치에서 넓어지게 되고, 이때 대구개공을 형성하며 후방으로는 소구개공이 존재 한다. 이러한 구개공들은 익돌구개관(ptery gopalatine canal) 의 하단부위를 나타내며, 이곳을 지나는 신경과 혈 관들이 경구개와 연구개를 지배하기 위하여 통과하게 된 다Fig. 4). 구개골의 후연(posterior margin)의 바로 앞쪽으로는 가로로 융기면이 존재하는데, 이 부위가 구 개긴장근(tensor veli palatini muscle)이 구개골에 부 착하는 가장 앞쪽 부분이다.

경구개의 혈액공급은 접형구개혈관 sphenopalatine vessel) 의 종말분지가 대구개공을 통과하는 대구개동맥과 정맥에 의하여 이루어진다. 대구개신경은 이차구개의 감 각신경을 담당하며, 상악신경의 분지로 절치와를 통과하 는 비구개신경( nasopalatine nerve) 가 일차구개의 감각 신경을 담당한다.

경구개는 구강의 다른 부위에 비하여 림프계가 풍부하 지 않다. 대부분은 상심부경정맥림프절이나 외측인두림 프절로 유입되며, 일차구개의 경우 악하림프절로 유입되

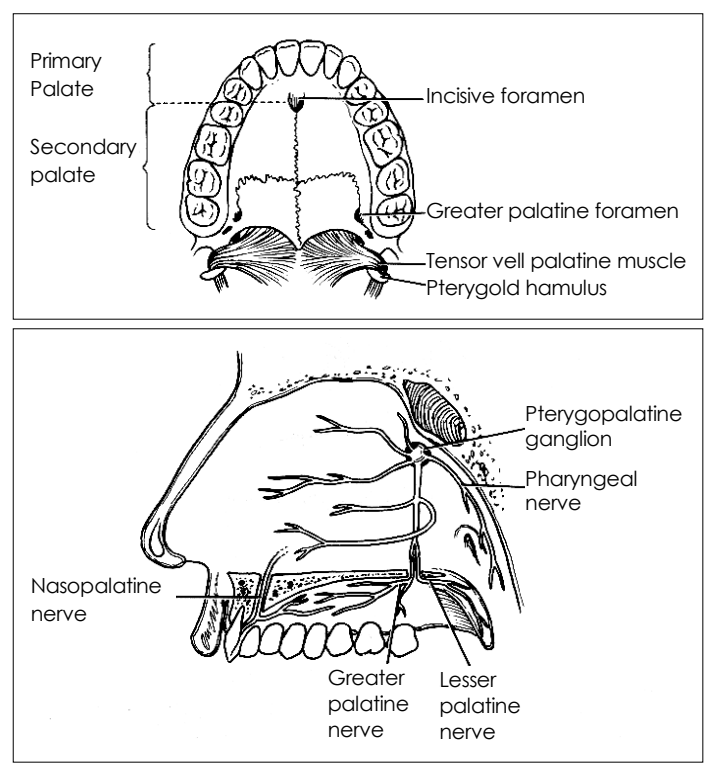

Fig. 4. Primary and secondary palates. Incisive fossa marks the union of the primary palate, which is innervate by nasopalatine nerve, and secondary palate, which is innervated by the greater palatine nerve.

기도 한다.

경구개는 구강의 다른 부위와는 다르게 악성종양 중 반수가 편평세포암종이고 나머지 반은 소타액선 기원이 며, 절제 범위는 조직학적 형태와 병기에 의해 결정된 다. 이학적 검사는 비내시경검사와 삼차신경(trigeminal nerve)에 대한 검사가 필요하다, 방사선학적 검사로는 골구조를 확인하기 위하여는 CT 가 도움이 되며, MRI는 삼차신경을 포함하여 심부의 삼차신경절( Gasserian ganglion)까지의 확인에 도움이 된다. 또한 술전 반드시 치과 검진을 하여야 하며, 필요한 경우 즉시 보조장치( obturator) 를 제작할 수 있어야 한다.

\section{구강저(Floor of Mouth)}

구강저는 하치조능의 내측면에서 혀의 복면(ventral surface) 에 이르는 초승달 모양의 부위를 말한다. 점막 이래는 하악설골근(my lohy oid), 이설골근(geniohy oid) 과 이설근(genioglossus) 이 근육막을 형성하고 있으며 점막하부에 설하선과 악하선관이 지난다.

양측의 하악설골근은 구강저 전방부위의 구조적인 지 
지를 담당하며, 설골설근(hyoglossus) 은 부분적으로 구 강저 최후방 부위를 지지한다. 외과적으로 중요한 해부 학적 구조는 설골설근과 여러 구조물과의 관계이다. 설 신경(lingual nerve), 악하선관, 설하선과 제 12 뇌신경 (hypoglossal nerve)은 설골설근의 외측에 위치하며, 내측으로는 설동맥( lingual artery) 이 위치한다(Fig. 5).

설동맥과 정맥이 구강저의 혈액공급을 담당한다. 설동 맥은 외경동맥( external carotid artery)에서 기시하여 설골설근 심부로 주행하여 구강으로 들어온다. 이때 분 지되는 배측설동맥(dorsal lingual artery)은 설근부를 담당하며, 종말분지인 설심부동맥( deep lingual artery) 과 설하동맥(suglingual artery)이 구강저의 혈액을 공 급한다.

구강저의 신경지배는 하악신경(V3)이 하악설골근을 지배하고 지각은 설신경분지가 담당한다.

구강저의 림프관은 광범위한 점막하림프관총에서 시작 되는데, 이것은 표층점막계(superficial mucosa system) 와 심부집합계( deep collecting sy stem) 을 형성한 다. 표층계는 구강저 전방에서 교차수입림프관을 가지며, 동측과 반대측의 전악하선림프절로 유입된다. 심부계는 최전방의 집합관만 교차가 일어날 뿐 동측의 전악하선 림프절로 유입된다. 구강저 후방에서는 직접 경정맥이복 근림프절(jugulodigastric lymph node)과 경정맥경동 맥림프절(jugulocarotid ly mph node) 로 유입된다.

구강저의 악성종양은 주로 중앙부위에 근접한 전방에 발생하며, 혀의 하부와 하악골과 같이 연속적인 구조물 을 침범한다. 종양의 침습은 악하선관과 설신경을 통해 서도 이루어지며, 하악골의 골막을 침범하면 하부로 하

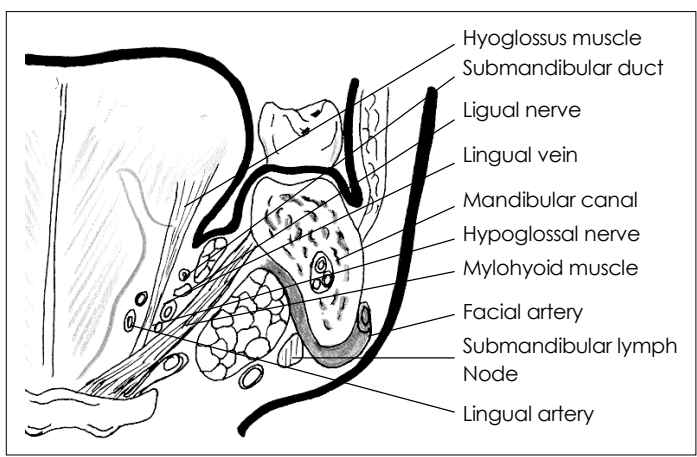

Fig. 5. Deep structures of the oral cavity : coronal section behind lst molar tooth.
악설골근을 거쳐 악하삼각부의 악하선과 피하조직 및 피 부까지도 이를 수 있다. 구강저의 종양이 혀의 전방 근육 을 침범하게 되면, 하부로는 설골에 이르고 드물게는 전 후두강(prelary ngeal space)까지 이를 수 있다.

구강저 종양에서 경부청소술을 시행하지 않고, 원발부 위 수술시 악하선관의 유두(papilla) 가 절제범위에 포함 된 경우에는 악하선관의 재이식이 필요하다.

\section{구강부 혀(Oral Tonge, Mobile Tongue)}

구강부 혀는 혀의 앞쪽 $2 \beta$ 를 이른다. 혀는 설첨(tip), 설연(lateral border), 설배(dorsum), 설하(undersurface) 의 네 개의 해부학적 영역으로 구분된다.

혀의 근육은 내근(intrinsic muscles) 과 외근( extrinsic muscles)으로 이루어져 있다. 내근은 독특하고 복 잡하게 서로 다른 방향의 세 개의 근육층으로 이루어져 있으며 중앙부는 설첨을 제외하고 설중격( septum linguae) 로 분리되어 있다. 내근의 기능은 발성이나 연하시 혀의 모양을 변화시키는 것이다. 외근은 이설근(genioglossus), 설골설근(hy oglossus) 과 경상설근( sty loglossus) 로, 혀의 모양을 변형시키고 혀를 전후방 또는 상 하로 당기는 것을 보조하는 기능을 담당한다 Fig. 6).

신경지배는 설하신경(hypoglossal nerve)이 외근과 내근을 담당하고, 지각신경은 하악신경의 설신경분지가

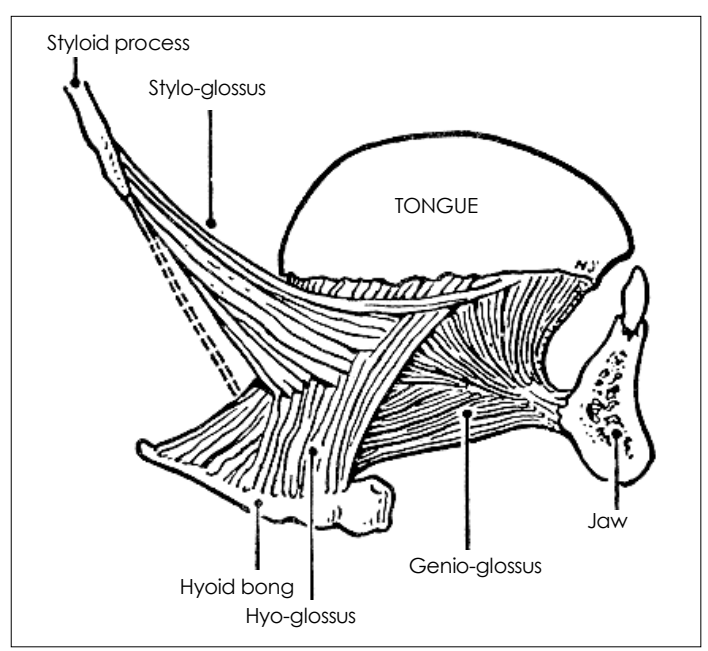

Fig. 6. The 3 extrinsic muscles of the tongue and their 3 bony origin. 


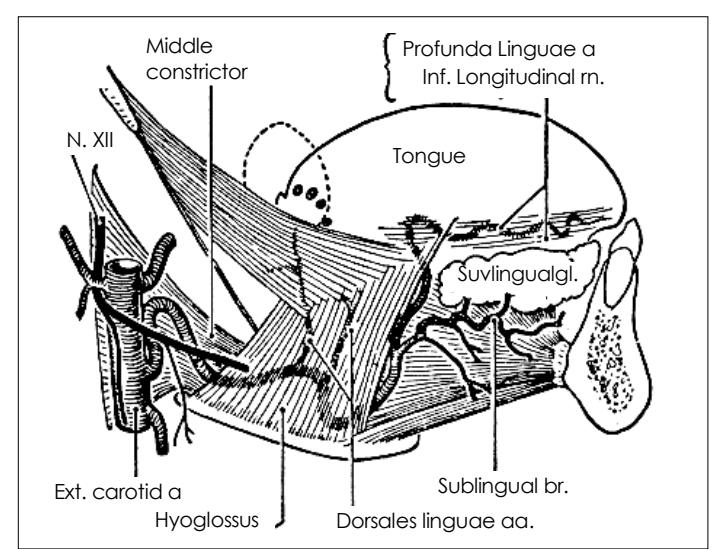

Fig. 7. Relative anatomy of the lingual artery.

지배하며 안면신경의 고삭신경분지가 미각을 담당한다.

혈액공급은 설동맥과 정맥이 담당한다. 설동맥은 외 경동맥의 분지로 이복근의 후복(posterior belly) 아래 쪽을 통과하여 앞쪽으로 진행하면서 편도분지를 내고, 설골 상부에서 설골설근의 후면에서 심부로 주행한다. 설골설근의 심부에서 분지하는 두개의 배측설동맥 분지 는 혀의 후방에 분포하며, 설골설근의 전연부에 이르러 종말분지인 설하동맥과 설심부동맥를 내면서 혀의 전방 $2 \beta$ 부위를 담당한다 Fig. 7).

수술시 설동맥의 혈류를 완전히 차단하고자 하는 경우 에는 외경정맥으로부터의 기시부에서 결찰하게 되면, 약 $20 \%$ 에서 설동맥과 안면동맥(facial artery)의 공통분지 (common branch) 를 형성하고 있기 때문에 많은 측부 혈행 (collateral circulation) 이 발생할 수 있으므로 설골 상부에서 설동맥을 찾아 결찰하는 것이 유리하다.

혀의 림프계는 풍부한 점막하림프관총을 통해서 이루 어지며 상심부경정맥림프절로 유입된다. 특히 설첨에 가 까운 림프관일수록 보다 하부 림프절로 유입될 수 있는 가능성이 있기 때문에 이학적 검사나 림프절 검사에서 이악하부나 악하삼각부에 전이 림프절이 발견되지 않은 경우 림프절 전이가 없을 것이라는 예상을 하는 것은 위 험하다Fig. 8). 또한 혀의 외측에 발생한 암종에서는 동 측 림프절에 먼저 전이되지만, 내측 중앙에 위치한 경우 에는 중앙림프관들이 교차유입을 하고 있으므로 양측 전 이의 가능성이 높다.

구강암에 있어 림프절 전이의 가능성은 원발병소의 위

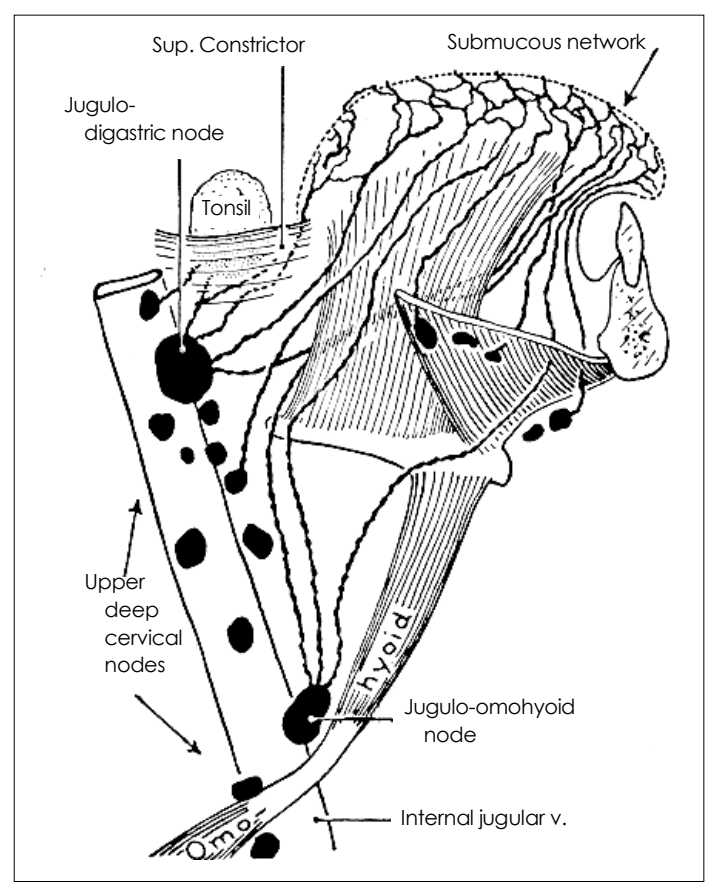

Fig. 8. Lymphatic drainage of the tongue.

치가 중요하다. 즉 동일병기의 설암이 협점막암에 비하 여 림프절 전이의 가능성이 높다. 일반적으로 림프절 전 이의 가능성은 혀에서 멀어질수록 낮아지는 경향이 있어, 위험도가 혀에서 가장 높고, 구강저, 하치조능, 협점막, 경구개의 순이다.

\section{중심 단어 : 구강. 해부학.}

\section{REFERENCES}

1) Baker SR, Krause CJ. Carcinoma of the lip. Laryngoscope 1980;90:19-27.

2) Esclamado RM, Krause CJ. Lip cancer. In: Bailey BJ, editor. Head and Neck Surgery Otolaryngology. 2nd ed. Lippincott-Raven;1998. p.1509-21.

3) Hollinshed WH. Anatomy for Surgeons: The Head and Neck. 3rd ed. Harper \& Row;1982. p.291-384.

4) McConnel FMS, Logemann JA, Rademaker AW, Pauloski $\mathrm{BR}$, Baker SR, Lewin J, et al. Surgical variables affecting postoperative swallowing efficiency in oral cancer patients: A pilot study. Laryngoscope 1994;104:87-90.

5) Jorgensen K, Elbrond O, Andersen AP. Carcinoma of the lip: A series of 869 cases. Acta Radiol 1973;12:177-90.

6) Kim KM, Kim YM, Shim YS, Kim KH. Epidemiologic survey of head and neck cancers in Korea. J Korean Med Sci 2003;18:80-7. 
7) Lindqvist C, Teppo L. Is upper lip cancer "true" lip cancer? J Cancer Res Clin Oncol 1980;97:187-91.

8) Kim SY. Malignant ncoplasms of the oral cavity and oropharynx. In: Kim JS, Chang SO, Lim HO, Lee JG, Lee CH, Wang SG, Cho JS. Editors. Otolaryngology Head and Neck Surgery. 1st ed. Lijogack;2002. p.1334-7.

9) Parker SL, Tong T, Bolden S, Wingo PA. Cancer statistics, 1997. CA. Cancer J Clin 1997:47:5-27.

10) Shah JP, Lydiatt WM. Buccal mucosa, Alveolus, Retromolar trigone, Floor of mouth, Hard palate, and Tongue tumors. In: Thawley SE, Panje WR, Batsakis JG, Lindberg RD, editors. Comprehensive Management of Head and Neck Tumors. 2nd ed. Philadelphia: Saunders;1999. p.686-94.

11) Sharma PK, Schuller DE, Baker SR. Malignant neoplasms of the oral cavity. In: Cummings CW, Fredrickson JM, Harker LA, Krause CJ, Schuller DE, Richardson MA, editors. Otolaryngology-Head and Neck Surgery. 3rd ed. St. Louis: Mosby Year Book;1998. p.1418-26.

12) American Joint Committee on Cancer. AJCC Cancer Staging Manual. 6th ed. Lippincott-Raven;2001. p.23-32.

13) Yang HS. Anatomy and physiology of the oral cavity and oropharynx. In: Kim JS, Chang SO, Lim HO, Lee JG, Lee CH, Wang SG, Cho JS, editors. Otolaryngology Head and Neck Surgery. 1st ed. Lijogack;2002. p.116-21.

14) Zitsch RP, Park CW, Renner GJ, Rea JL. Outcome analysis for lip carcinoma. Otolaryngol Head Neck Surg 1995; $113(5): 589-96$. 